\title{
Determinants of Small Holder Rural Farm Households' Participation in Small Scale Irrigation in Western Ethiopia, in Case of Assosa District in Assosa Zone (Heckman Two-Stage Model)
}

\author{
Adisu Yirdaw Abdu Ahmed ${ }^{*}$ \\ Department of Economics, Assosa University, Ethiopia
}

\begin{abstract}
Increasing technology adoption including irrigation among smallholder farmers has a big potential to uplift living standards of poor through increasing production and consumption pattern. The objective of this study was analyzing determinant of smallholder farmer participation in small scale irrigation and its intensification in western Ethiopia, in case of Assosa district in Assosa Zone. The study used data from 329 respondents from six selected kebeles of Assosa woreda in Assosa zone, through structured questioner. The descriptive statistics and Heckman two stage econometric methods were employed to analyze data collected from sampled household. The significance of coefficient of inverse Mill's ratio $(\lambda)$ indicates the presence of selection bias and the effectiveness of applying Heckman two stage model. In the first stage of probit regression results of study show that the adoption decision of small scale irrigation use were driven by factors such as sex of the head, education, farm size, attend training at farmer training center, distance to irrigation, credit use, total livestock unit, ethnicity, active labor and development agent advice significantly determine participation in small scale irrigation. In the second stage, the intensification of small scale irrigation use was influenced by family size, credit use, ethnicity of farm household head and lambda. The policies which expand the accessibility of credit service, dissemination of productive agricultural technology information, and creating opportunity of education for farm household has potential to increase the chance of small scale irrigation adoption decision and strengthen the level of adoption among smallholder farmers.
\end{abstract}

Keywords: Assosa, Hechman two stages, Small scale irrigation adoption

DOI: $10.7176 / \mathrm{JRDM} / 73-01$

Publication date: February $28^{\text {th }} 2021$

\section{INTRODUCTION}

The study of how individuals are able to escape poverty is a central issue of economic development theory. Of the poor people worldwide (those who consume less than a 1 dollar-a-day), 75 percent work and live in rural areas and projections suggest that over 60 percent will continue to do so up to 2025 (Mendola, 2007). These are good reasons to give emphasis to research on rural poverty reduction, and to redirect attention and expenditure towards agricultural development.

In Less Developed Countries (LDCs) in general and Sub-Saharan Africa (SSA) in particular, economic policy highly rely on agriculture. Poverty reduction and the growth of income can generally be realized through agricultural growth that creates spillover effects to the remaining sectors (World Bank, 2014). However, production and productivity of the agricultural sector in SSA is low due to low technological adoption including irrigation and techniques among others (Abraham et al., 2014; Gashaw et al., 2014). Agriculture provides largely to the economic growth of many low income countries like Ethiopia with the potential of irrigation. Since, agriculture is the leading sector of the economy as source of income, employment and foreign exchange. Additionally, more than half of the less developed countries population gets their food from own production. The country used this agricultural output as an input for industries so it can stimulate the growth of industrialization. Hence, agriculture is Ethiopia's most important sector and it is the main stay of economy that contributes about $34.122 \%$ of the Gross Domestic Product (GDP), $75 \%$ of the employment of the country's labor force, $70 \%$ of export earning and $70 \%$ of the supply of industrial raw materials (FAO, 2017).

Drought is becoming frequent and many people have been repeatedly exposed to hunger and famine due to the high rainfall dependency of the agricultural production in Ethiopia. Depend on this, the Ethiopian government use different strategies to avoid or minimize the deep-rooted food insecurity at the household level. Among these strategies the introduction of different water harvesting schemes for the farmers to be able to produce enough for the whole year round is the major one. Hence, both government and non government organizations in Ethiopia have been initiating and implementing micro irrigation projects because irrigation contributes to livelihood improvement through increased income and food security, employment opportunity and poverty reduction (Tsegazeab, 2016). Therefore, this calls for different interventions, irrigation being one of the options, which could help in adapting strategies to cope up with the challenging drought and to ensure food security as well as the 
household income at national level in general and household level in particular.

There is a high irrigation potential in Benishangul Gumuz region, but its level of utilization is not as per its potential. Contrasting to its natural endowment like water accessibility, the developments of irrigation in the region and specifically in the study district is the lowest and hence, this necessitates conducting an empirical analysis to verify the factors responsible for low status of adopting irrigation practice in the study area. In the study area there is large number of small holder rural farmers that is known by practicing small scale irrigation that consisting of high irrigation potential, but the potential available for irrigated farming is not intensively used. There is limited scientific evidence why the farmers in the study area are not using this potential to increase their production and improve their income. Therefore, this study was mainly concerned to find out the factors that determine the farmer's adoption decision in small scale irrigation practice and intensity of participation in the study area.

The adoption of more efficient farming practices and technologies that augment agricultural productivity and improve environmental sustainability is instrumental for achieving economic growth, food security and poverty alleviation. In line with this, the Woreda has constructed different irrigation schemes having the objective of increasing agricultural productivity to improve the food security situation of the farming communities and to decrease reliance on the erratic rainfall. However, a significant attempt has not been made to study and analyze the determinant and intensity of small scale irrigation of rural farmers in the study area. Not only in the study area, especially the study on intensity of participation in irrigation practice is scanty as a whole in the country and globally. Beside as per the knowledge the researcher, in the Woreda there are different ethnic groups, among these groups there are indigenous and settlers. Therefore variables like ethnicity difference (i.e. indigenous or new settlers) and duration of residence were included in this study as explanatory variables that no one dealt with. Therefore, this study was designed to identify demographic, institutional and socio-economic factors that determine the smallholder farm house hold irrigation adoption decision and extent of adoption.

\section{LITERATURE REVIEW}

New technology adoption is a decision-making process in which an individual passes from first knowledge of an innovation, to forming an attitude toward an innovation, to a decision to adopt or reject, to implementation of new idea, and to confirmation of the decision (Ray, 2001). Agricultural technology adoption states to the decision to use a new technology, method, practice, etc. by a farmer (Feder, Just \& Zilberman, 1985). On the other hand, extent of technology adoption is defined as the level of adoption of a given technological package among user (Nkonya, Schroeder \& Norman, 1997). The expansion of new agricultural technology application has increased agricultural productivity, contributed to overall economic growth, and reduced food insecurity and poverty in developed and some developing countries (Bandeira \& Rasul, 2005; Cornejo \& McBridgje, 2002).

Different research on technology adoption across various region witness that demographic, institutional and socio-economic factor affects the farm house hold decision to adopt new technology and its intensification. Using double hurdle model in Ethiopia, Temesgen (2018), found that number of oxen, market distance, farm distance from irrigation water source, market information and credit use significantly determine participation in small scale irrigation. The analysis from truncated part of double hurdle model shows that age, number of oxen owned, market distance, education level, road distance and access to credit significantly determine the intensity of participation in small scale irrigation. The demographic factor such as sex of a respondent is mostly used as one of determinant factors of participation in irrigation and found that male headed households are the most likely participant in small scale irrigation practice (Kinfe et al., 2012; Muhammad et al., 2013; Gebrehaweria et al., 2014) and irrigate more area (Abebe et al., 2011). Likewise, the variable age of household head also shown that it affects the area of land allocated for improved irrigation technology negatively (Wang et al., 2015; Pokhrel $\boldsymbol{e t}$ al., 2016). This indicate that the more aged the farmers, they allocate more of their land to non improved traditional farming practice rather than improved technology such as irrigated farming, because older farmers have shorter plan of living at this age.

More ever, Leta et al., (2018), examined that age, educational level, contact frequency with agricultural development agent, access to mass media, participation in irrigation related training and livestock ownership were the variables that significantly influence households' use of small scale irrigation. Astatike (2016), applying Heckman selection model (two staged) in Bahir Dar Zuria Woreda examined that the decision of farmers to adopt small scale irrigation were determined by the different socio economic, demographic and institutional variables such as owning irrigation land, having pumping motor and dissatisfaction with the existing irrigation schemes are the most significant influencing factors that determine irrigation participation.

The above studies of the empirical literature showed that socio-economic, demographic characteristics and institutional variables like education level of household, access to credit, livestock holding, access to extension contact, owning irrigation land, access to mass media, distance to market and availability of farm labor are influence adoption and intensity of small scale irrigation. 


\section{METHODS}

\section{Description of the study area}

This study emphasized on Benishangul-Gumuz Regional State particularly Assosa woreda. According to the national census of 2018 done by Central Statistics Agency of Ethiopia, the total population of Assosa woreda reported is 104,147. Assosa Woreda which has 74 rural kebeles, total area approximately 2,903 square kilometer and located at a distance of $667 \mathrm{~km}$ in West of Addis Ababa (BoFED, 2017). The rainy season starts from April/May up to October/November with an average annual rain fall that ranges from $800 \mathrm{~mm}$ to $2000 \mathrm{~mm}$. The temperature ranges from $20^{\circ} \mathrm{C}-35^{\circ} \mathrm{C}$ (highest) to $12^{0} \mathrm{C}-20^{\circ} \mathrm{C}$ (lowest) (BOFED, 2014).

Due to agricultural dependence on rain water, many crops are planted during rainy seasons (Meher). The dominant cereal crops like maize, teff, pulses and sorghum produced in Meher season and collected from October to January. Beside, fruits like Mango, Banana and Papaya and vegetables like Cabbage, Tomato, Onion, Sweet potato as well as many crops and vegetables are produced by many rural small holder farmers. Like other rural areas, in Assosa Woreda of the dwellers, the source of the population livelihood also depends on the practice of mixed agricultural farming system especially practice of small scale irrigation.

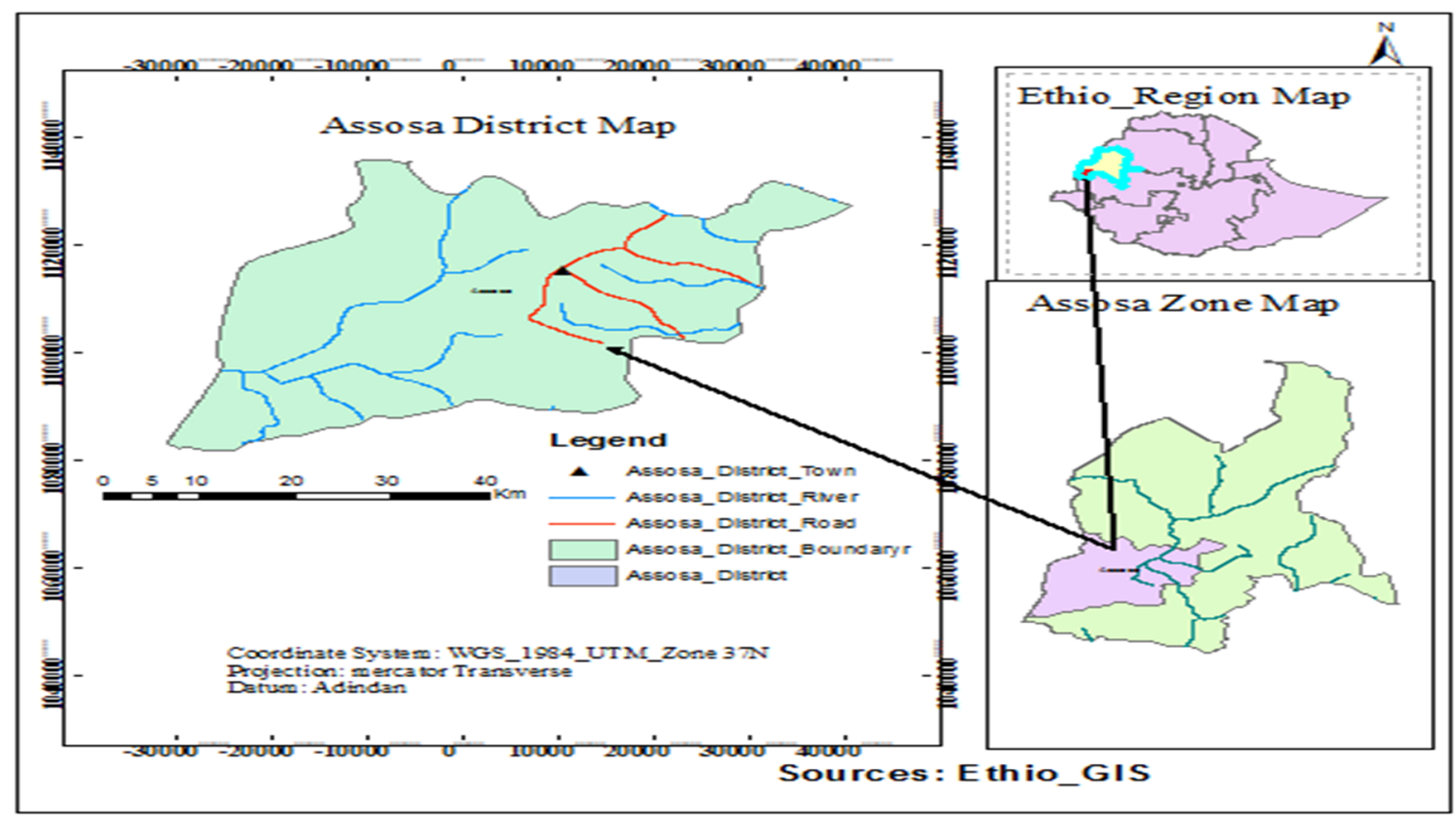

Figure 1: The Location of Assosa district in Ethiopia

\section{Research strategy}

In this inquiry, both quantitative and qualitative research strategies was employed. The quantitative strategy used to investigate the data that was collected using structured questionnaire from 329 sampled farm household heads. The qualitative research strategy used to analyze data that was collected using the unstructured interviews with local traders; rural experts; kebele administrative body; and consumers to capture supplementary information and to observe the validity of information's from household survey.

\section{Research design}

The cross-sectional (survey) research design was applied in this study. Accordingly, demographic, socio-economic and institutional data related to small scale irrigation adoption status of smallholder farm family was collected for the harvest year of 2019/20 and analyzed through econometric and descriptive methods.

\section{Sampling size determination}

The samples for this study distinguished according to the formula for sample size determination for finite population given by (Yamane, 1967) as shown below;

$$
n=\frac{\mathrm{N}}{1+N(e)^{2}}
$$

Where " $\mathrm{n}$ " is required sample size, " $\mathrm{N}$ " the total number of households in the selected kebeles (1847hhs) and "e" acceptable error margin (0.05).

Thus, the total sample size can be calculated by using the above formulas. 


$$
n=\frac{1847}{1+1847(0.05)^{2}}=329
$$

Therefore in this study the number of sample households is 329 and then to determine each kebeles sample size using probability proportional sampling technique, is computed as follows;

$$
n=\frac{N i}{\sum_{i=1}^{k=6} N} * n
$$

Where "ni" is sample size of $\mathrm{i}^{\text {th }}$ kebele, "Ni" total household of $\mathrm{i}^{\text {th }}$ kebele, " $\sum_{i=1}^{k=6} N$ " total number of household in the selected six kebeles and " $\mathrm{n}$ " total sample size.

Table 1: Stratified and proportionately selected sample size determination

\begin{tabular}{lccllllll}
\hline Kebeles & \multicolumn{2}{c}{$\begin{array}{c}\text { Household No. of No. of } \\
\text { nos }\end{array}$} & users & \multicolumn{2}{c}{$\begin{array}{c}\text { How to } \\
\text { non-users }\end{array}$} & \multicolumn{2}{c}{ Total Sampled Sample } & sample \\
& compute & size & users & non-users & \\
\hline Mengele 39 & 281 & 131 & 150 & $281 / 1847 * 329$ & 50 & 23 & 27 & \\
Amba 11 & 304 & 121 & 183 & $304 / 1847 * 329$ & 54 & 21 & 33 & \\
Selga 22 & 290 & 160 & 130 & $290 / 1847 * 329$ & 52 & 29 & 23 & \\
Mengele 32 & 310 & 115 & 195 & $310 / 1847 * 329$ & 55 & 20 & 35 & \\
Mengele 29 & 320 & 120 & 200 & $320 / 1847 * 329$ & 57 & 21 & 36 & \\
Amba 13 & 342 & 178 & 164 & $342 / 1847 * 329$ & 61 & 32 & 29 & \\
\hline Total & $\mathbf{1 8 4 7}$ & $\mathbf{8 2 5}$ & $\mathbf{1 0 2 2}$ & & $\mathbf{3 2 9}$ & $\mathbf{1 4 6}$ & $\mathbf{1 8 3}$ &
\end{tabular}

Source: Kebeles administrative office and own computation (2020)

\section{Methods of data analysis}

In this study the descriptive statistics such as mean, standard deviation, percentages, frequency, t- test, Chi-square and graphs were used in analyzing the data. Furthermore, the dependent variables in this study are the adoption decision of the farmers in small scale irrigation. Since the dependent variables of this study, household's adoption decision in small scale irrigation is dichotomous (binary), it takes a value of 1 if the household is adopter of small scale irrigation and zero otherwise. Therefore, the dependent variable in this model is discrete consisting of two outcomes, yes or no. In this case, using Ordinary Least Square/OLS technique for such variables poses inference problems, and thus not appropriate for investigating dichotomous or limited dependent variables. In such circumstances, maximum likelihood estimation procedures such as logit or probit models are generally more efficient (Gujarati, 1995).

Several investigators used different models for analyzing the determinants of small scale irrigation adoption at farm level. Various adoption studies have used Tobit model to estimate adoption relationships with limited dependent variables while the others used double-hurdle model. However, it is conceivable to use Heckman's (1979) two step procedure in case of anticipated problem of selection bias in the sample. Selection bias was anticipated in this study because among the representative not all households are believed to participate in small scale irrigation adoption due to individual problems.

The Heckman two-step selection model allows for separation between the initial decision to adopt technology, including irrigation $(Y>$ versus $Y \leq 0)$ and the level of their application. The model uses in the first step a probit regression to assess the probability of decision to adopt and in the second step uses ordinary least squares (OLS) to determine the intensity of adoption (Green, 2007) and the method correct sample selection bias. This technique used in order to control the selectivity bias and endogeneity problem and to obtain consistent and unbiased parameter estimates (Green, 2007). In selection model procedure, sample bias is determined by the relationship between the residuals of the two stages (stage 1 and stage 2). Estimates are biased if the residuals in the stage 1 and 2 are correlated. Similarly, Stage 1 does not affect stage 2 results if the residuals are unrelated. Positive and negative correlations between residuals are indicated respectively, by positive and negative $\mathrm{mu}(\mu)$ values, which is the correlation between error terms of two regression model.

The first stage Heckman two steps or the probit model is to analyze the factors determining the probability of adopting small scale irrigation and specified as:

$$
\operatorname{pr}\left(Y_{1 i}=1 / x_{1 i}, \beta_{1 i}\right)=\Phi\left(f\left(x_{1 i}, \beta_{1 i}\right)\right)+\varepsilon_{\mathrm{i}}
$$

Where; $Y_{1 i}$ is an indicator variable that is equal to unity for small scale irrigation user households; $\Phi$ is the standard normal cumulative distribution function; $x_{1 i}$, is variable that affect adoption decision and was described in Table $2 ; \beta_{1 i}$ is a coefficient to be estimated. The variable $Y_{1 i}$ takes the value 1 if the household is adopter of small scale irrigation and 0 otherwise. This can be shown mathematically:-

$$
Y_{1 i}^{*}=\beta_{0}+\beta_{1 i} X_{1 i}+\varepsilon_{\mathrm{i}}
$$

Where; $\mathrm{i}=1,2,3 \ldots \ldots \ldots \ldots \ldots \ldots . \mathrm{n}$

$$
Y_{1 i}=\left\{\begin{array}{l}
1 \text { if } Y_{1 i}^{*}>0 \\
0 \text { if } Y_{1 i}^{*} \leq 0
\end{array}\right.
$$


Where $Y_{1 i}^{*}$ is a latent variable of marginal utility the farmer's get from adoption of small scale irrigation, $\beta_{0}$ is constant term, $\varepsilon_{\mathrm{i}}$ is error terms in the first stage model assumed to be normally distributed with zero mean and constant variance $\left(\delta^{2}\right)$.

In the second stage parameters can consistently be estimated by OLS by incorporating an estimate of the inverse Mills ratios denoted as $\lambda_{i}$ from probit regression model as additional explanatory variable as specified bellow:-

Where:

$$
Y_{2 i}=\alpha_{0}+\alpha_{i} X_{2 i}+\mu_{i} \lambda_{i}+v_{\mathrm{i}}
$$

$Y_{2 i}=$ represents the proportion of land allocated for small scale irrigation by the farmer,

$X_{2 i}=$ implies the explanatory variables determining the intensity of participation in small scale irrigated farming shown in Table 2 ,

$\alpha_{0}=$ is the constant term in OLS regression model,

$\alpha_{i}=$ is the parameters to be estimated in the second stage,

$\lambda_{i}=$ is the inverse mills ratio computed from first stage estimation,

$\mu_{i}=$ implies the correlation between first and second stage error terms or corr $\left(\varepsilon_{\mathrm{i}}, v_{\mathrm{i}}\right)$,

$v_{\mathrm{i}}=$ is the error terms in the second stage.

According to Heckman (1979), the IMR $\left(\lambda_{i}\right)$ is a variable for controlling bias due to sample selection. This term is constructed using the model in the probit regression (first stage) and then incorporate into the model of the second stage (OLS) as an independent variable. It can obtain:-

$$
\lambda_{i}=\frac{\phi\left(\beta_{0}+\beta_{1 i} X_{1 i}\right)}{\Phi\left(\beta_{0}+\beta_{1 i} X_{1 i}\right)}
$$

Where, $\phi\left(\beta_{0}+\beta_{1 i} X_{1 i}\right)$ denotes the standard normal probability density function and $\Phi\left(\beta_{0}+\beta_{1 i} X_{1 i}\right)$ denotes the cumulative distribution function for a standard normal random variable.

But the value of $\lambda_{i}$ is not known, the parameters $\beta_{0}$ and $\beta_{1 i}$ can be estimated using a probit model, based on the observed binary result. Then the estimated IMR calculated as:-

$$
\widehat{\lambda_{l}}=\frac{\phi\left(\widehat{\beta_{0}}+\widehat{\beta_{1 \imath}} X_{1 i}\right)}{\Phi\left(\widehat{\beta_{0}}+\widehat{\beta_{1 \imath}} X_{1 i}\right)}
$$

\section{Hypotheses and justification of explanatory variables}

One of the important parts in this section is to specify and hypothesize the dependent and explanatory variables that were used in the model. Regarding to its definition, measurement and hypotheses of variables, which was used in our model, summarized in the Table 2.

\begin{tabular}{|c|c|c|c|c|}
\hline Code & Definition & Scale measurement & $\begin{array}{l}\text { Nature of } \\
\text { variables }\end{array}$ & $\begin{array}{l}\text { Expected } \\
\text { effect }\end{array}$ \\
\hline Irrgg & Small scale irrigation adoption decision & $\begin{array}{l}\text { User }=1 \\
\text { Non } \text { user }=0\end{array}$ & Binary & \\
\hline Pirrl & Proportion of land irrigated & In hectare & Continuous & \\
\hline Aghh & Age of farm household head & In year & Continuous & -+ \\
\hline Sexhh & Sex of farm household head & 1 if male, 0 otherwise & Dummy & + \\
\hline Fshh & Family size of households & In number & Continuous & + \\
\hline Eduhh & Education status of the head & 1 if literate, 0 otherwise & Dummy & + \\
\hline Duresi & Duration of residence & In years & Continuous & + \\
\hline Ethi & Ethnicity of farm household head & $\begin{array}{l}\text { Indigenous }=1 \\
\text { Settler }=0\end{array}$ & Dummy & +- \\
\hline Sicl & Size of cultivated land & In hectare & Continuous & + \\
\hline Usecrids & Use of credit services & Yes $=1,0$ otherwise & Dummy & + \\
\hline Livow & Livestock ownership & TLU & Continuous & + \\
\hline Distmkt & Distance to the market & In Km & Continuous & - \\
\hline Offfarm & Participate in nonfarm activity & Yes $=1,0$, otherwise & Dummy & + \\
\hline Distirr & Distance of plot of land from water source & In $\mathrm{Km}$ & Continuous & - \\
\hline Das & Contact with development agent advice & $\begin{array}{l}\text { Frequency of contact with } \\
\text { Das }\end{array}$ & Continuous & + \\
\hline Parlfor & Participation of farm labor force & In number & Continuous & + \\
\hline Atftc & $\begin{array}{l}\text { Attending training at farmer training } \\
\text { center }\end{array}$ & Yes $=1,0$ otherwise & Dummy & + \\
\hline
\end{tabular}

Table 2. Explanation of hypothesized effect of explanatory variables on small scale irrigation adoption and its intensity 


\section{RESULTS AND DISCUSSION}

Descriptive analysis

Out of total sample of 329 smallholder farm household, 146(44.4\%) participated in adoption of small scale irrigation in their cultivation, while the remaining $183(55.6 \%)$ were no practicing small scale irrigation. Table 3 illustrate the mean, minimum and maximum age of head, size of land ownership, distance to market center, number of family, size of active family, distance to irrigation, total livestock unit, development agent advice and duration of residence for total survey, irrigation adopter and non-adopter in comparison.

The descriptive statistics result for continuous variable (Table 3, t-value) show that there was no statistically significant difference between small scale irrigation adopter and non-adopter concerning age of head and distance to market center while there was significant difference in land holding and handiness of family labor. This demonstrates the importance of family labor force and arable land whether the household to adopt or not to adopt productive technology.

Table 3. Description of continuous variables

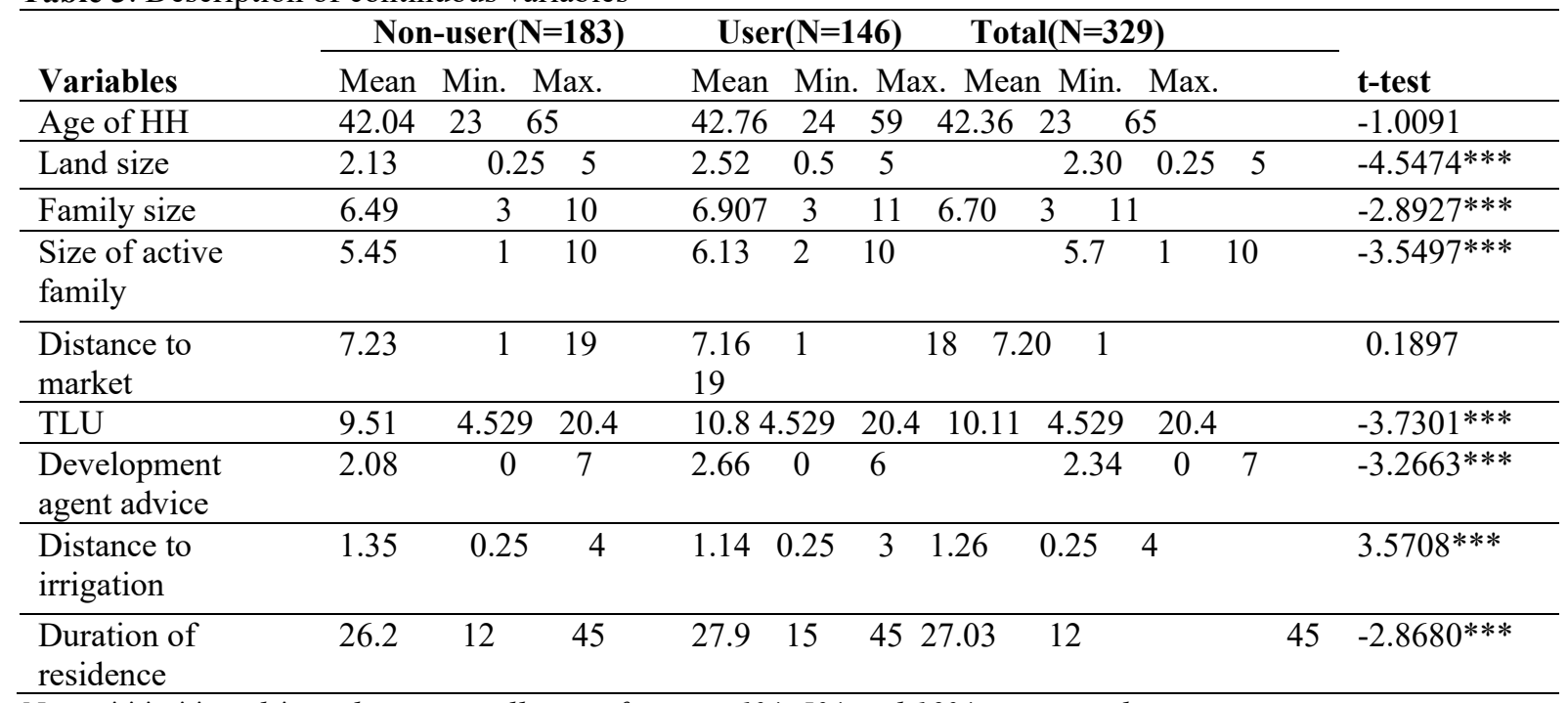

Note: $* * *, * *$ and $*$ imply statistically significant at $1 \%, 5 \%$ and $10 \%$ respectively.

Source: Computed from own survey data (2020)

Table 4. Summarizes frequency, percentage and level of influence of dummy variable. Accordingly, there was statistically significant difference between users and non-users of irrigation in education level of head, sex of the head, ethnicity of the head, attained training at farmer training center, affordability of credit and participation in nonfarm activities.

Table 4. Description of dummy variables

\begin{tabular}{|c|c|c|c|c|c|c|c|}
\hline \multicolumn{8}{|c|}{ Irrigation } \\
\hline Variables & Type & Non-users & Users & \multicolumn{2}{|l|}{ Total } & \multicolumn{2}{|c|}{ Percent $\mathrm{Chi}^{2}$-test } \\
\hline \multirow{2}{*}{$\begin{array}{l}\text { Sex of household } \\
\text { head }\end{array}$} & Female & 64 & 32 & 96 & & 29.18 & \\
\hline & Male & 119 & 114 & 233 & & 70.82 & $6.8109 * * *$ \\
\hline \multirow{2}{*}{$\begin{array}{l}\text { Education status of } \\
\text { the household head }\end{array}$} & Illiterate & 7842 & \multirow[t]{2}{*}{105} & 120 & 36.47 & \multirow{2}{*}{\multicolumn{2}{|c|}{$6.8030 * * *$}} \\
\hline & Literate & 104 & & 209 & 63.53 & & \\
\hline \multirow{2}{*}{$\begin{array}{l}\text { Participate in non- } \\
\text { farm activity }\end{array}$} & No & 127 & \multirow{2}{*}{$\begin{array}{c}71 \\
75\end{array}$} & 198 & & \multicolumn{2}{|l|}{60.18} \\
\hline & Yes & 56 & & 131 & & 39.82 & $14.6522 * * *$ \\
\hline \multirow{2}{*}{$\begin{array}{l}\text { Attending training } \\
\text { at FTC }\end{array}$} & No & 147 & 52 & 209 & & 6353 & \\
\hline & Yes & 36 & 84 & 120 & & 36.47 & $51.1696 * * *$ \\
\hline \multirow{2}{*}{$\begin{array}{l}\text { Have access to } \\
\text { credit }\end{array}$} & No & 117 & 58 & 175 & & 53.19 & \\
\hline & Yes & 66 & 88 & 154 & & 46.81 & $19.2702 * * *$ \\
\hline \multirow{2}{*}{$\begin{array}{l}\text { Ethnicity of } \\
\text { household head }\end{array}$} & Settler & 103 & \multirow[t]{2}{*}{109} & 212 & & \multicolumn{2}{|l|}{64.44} \\
\hline & Indigenous & 80 & & 117 & & 35.56 & $12.1799 * * *$ \\
\hline
\end{tabular}

Note: $* * *, * *$ and $*$ imply statistically significant at $1 \%, 5 \%$ and $10 \%$ respectively.

Source: Computed from own survey data (2020)

\section{An econometric estimation results}

In this sub-section, Heckman two stage selection analysis is executed to identify the household-level demographic, 
socio economic and institutional factors that determine the decision of smallholder farmers to adopt or not to adopt small scale irrigation in the first stage by applying probit regression. In the second stage, the conditional estimation/OLS method was used to investigate factors that influence the level of their adoption.

However, before running the regression analysis, the diagnostic tests, such that, the existence of multicollinearity and the problem of heteroscedasticity of variables included in the model are needed to be checked for explanatory variables. According to Gujarat (2004), when the values of VIF approach to infinitive there is serious problem of multicollinearity, while if VIF is below 10 there is no much problem. In this study all the computed value of VIF for explanatory including IMR variable was blow five. Therefore, there is no evidence of multicollinearity problem among the explanatory variables included in the model. The data were also tested for heteroscedasticity using the Breusch-Pagan test (Wooldridge, 2012). The Breusch-Pagan test evaluates the null hypothesis of a constant variance in the data. The Chi-square value results of STATA output were presented in appendix---. Accordingly, the null hypothesis of a constant variance was not rejected implying absence of heteroscedasticity in survey data.

Factors determining farmer's small scale irrigation adoption decision

Table 5 shows the probit regression and marginal effect of probit outcomes of factors that influence the likelihood of farmer's small scale irrigation adoption decision. The models constructed with 15 independent variables and out of these 10 variables are significantly determining the adoption decision with hypothesized sign. These variables include size of farm land, ethnicity of the household head, livestock ownership, sex of household head, education status of household head, participation in labor force activity, distance to irrigation, access to credit service, attending training at farmer training center and development agent advice are statistically significant and economically meaning full results, that affects the probability of small scale irrigation participation. Whereas, age of household head, size of family, duration of residence, distance to the nearest market and participating in nonfarm activity insignificantly but all variables with expected sign influence the small scale irrigation adoption decision.

Table 5: Factors that determine farmer's small scale irrigation adoption decision - Probit model

\begin{tabular}{|c|c|c|c|c|c|}
\hline \multirow[t]{2}{*}{ Variables } & \multicolumn{3}{|c|}{ Parametric estimation } & \multicolumn{2}{|c|}{ Marginal effect } \\
\hline & Coefficient & Std.Err. & $\mathrm{z}$ & $\begin{array}{l}\text { Coefficient/dF } \\
/ \mathrm{dx}\end{array}$ & Std. Err. $\quad \mathrm{P}>|\mathrm{z}|$ \\
\hline Aghh & .0160794 & .0135569 & 1.19 & .0062897 & $\begin{array}{ll}.0053 & 0.235\end{array}$ \\
\hline Sexhh & .4177582 & .1857535 & 2.25 & $.1589477 * *$. & $.06798 \quad 0.019$ \\
\hline Fshh & .0706669 & .0550746 & 1.28 & $.0276425 \quad .0$ & 021540.199 \\
\hline Sicl & .3307449 & .1087438 & 3.04 & $.1293761 * * *$ & $\begin{array}{ll}.0425 & 0.002\end{array}$ \\
\hline Livow & .0461188 & .0241873 & 1.91 & $.0180401 *$ & $\begin{array}{ll}.00946 & 0.057\end{array}$ \\
\hline Parlfor & .1177497 & .0484966 & 2.43 & $.0460597 \quad *$ & ** $\quad 018950.015$ \\
\hline Distirr & -.4612583 & .1704456 & -2.71 & $-.1804284 * * *$ & .06650 .007 \\
\hline Distmkt & -.0069122 & .025065 & -0.28 & -.0027038 & $\begin{array}{ll}.00981 & 0.783\end{array}$ \\
\hline Eduhh & .3033379 & .1821193 & 1.67 & $.1171707 *$ & .069120 .090 \\
\hline Ethi & -.5470826 & .1734323 & -3.15 & $-.2076232 * * *$ & .0630 .001 \\
\hline Duresi & .0147623 & .015205 & 0.97 & .0057745 & $\begin{array}{lll}.00595 & 0.331\end{array}$ \\
\hline Offfarm & .1961275 & .1759148 & 1.11 & .0768882 & 069010.265 \\
\hline Usecrids & .3790371 & .1655754 & 2.29 & .1477575 & .063920 .021 \\
\hline Das & .135666 & .0514173 & $3 \quad 2.64$ & $.0530679 * * *$ & .020140 .008 \\
\hline Atftc & .992518 & .1719034 & $4 \quad 5.77$ & $.0530679 * * *$ & $.0201 \quad 0.000$ \\
\hline Con & -4.257388 & .9137255 & -4.66 & & \\
\hline
\end{tabular}

Number of observation $=329 ;$ LR chi2 $(15)=139.09 ;$ Probability $>$ chi $2=0.0000$

Log likelihood = -156.41297; Pseudo $R^{2}=0.3078$

$* * *, * *$ and $*$ imply statistically significant at 1,5 and $10 \%$ respectively.

Source: Computed from own survey data (2020)

As specified in Table 5, the marginal effect report of the probit regression provides the probability that a farm household able to adopt small scale irrigation. Accordingly, the interpretations of each significant variable were explained here under.

The farm size of respondent was positive and had statistically significant influence at $1 \%$ level on the adoption of small scale irrigation. The marginal effect result indicates that a farmer, who has one additional hector of arable land, would increase the likelihood of small scale irrigation adoption by $12.93 \%$. This result is in line with the argument of the previous study which was done by (Beyan; Jafer \& Adem, 2014) and Abebaw (2015) which claimed that larger arable land ownership enable farmers to have more flexible in their decision making, greater access to discretionary resource, and give more opportunity to adopt new farm practice including irrigation.

In line with prior expectation, sex of household head was positive and had statistically significant influence 
at $5 \%$ level on the adoption of small scale irrigation. The result indicates that female headed households are 15.9 percent of marginal effect less likely to participate in small scale irrigation; other things remain constant, as compared to their counterparts of male. This finding is similar with (Gebregziabher, Regassa \& Holden, 2012) \& Tsegazeab (2016) and according to their finding the probable reason is due to cultural biases where female headed households have limited resource access and males have more exposure to other social and economic activities and the above results coincide with this effect.

As hypothesized, distance to irrigation water was found to be negatively and significantly influenced the probability of adoption of small scale irrigation decision at $1 \%$ significance level. Keeping other variables constant at their respective mean level, the probability of participating in irrigation for a household decreased by $18.04 \%$ as the distance of water source from his/her plot of land increase by one kilometer. This implied that the longer the distance between a plot of land and the irrigation water, the lower will be the probability of adoption of small scale irrigation. This finding is similar with Beyan, (2014) and Petros, (2017).

In the same genre, development agent advice was statistically significant and positively affects participation in irrigation at $1 \%$ probability level. The marginal effect verify that receiving extension service for one more day augments the likelihood of adopting small scale irrigation technology by 5.3 percent, citreous paribus. It implied that extension workers play a fundamental role in transferring knowledge to the farmers easily thereby improving production, income and food security and it is consistent to the previous hypothesis stated in this study. The result is in line with the empirical finding of Kidanemariam et al., (2017) which claim that contact with extension services gives farmers greater access to information on technology, via communications and more opportunities to participate in demonstration tests.

As hypothesized, education level of household head was found to be positively and significantly influenced the probability of adoption of irrigation. Holding other variables constant, as compared to illiterate farmers the probability of adoption of small scale irrigation for literate farmers would increase by $11.7 \%$. This is due to the fact that educational attainment by the household head could lead to awareness of the possible advantages of modernizing agriculture by means of technological inputs; able to understand and apply different sort of irrigation technology in their farm land which, in turn, would enhance households' food supply. This result is consistent with work of Ogunniyi et al., (2018), they forwarded that having education increases the probability of adoption of irrigation by farmers.

As expected, attending training at farmer training center has shown positive influence on likelihood of small scale irrigation adoption decision at $1 \%$ level of significance. Keeping other variables constant, a farmer who attend training at farmer training center have $5.3 \%$ better opportunity to adopt small scale irrigation than those who is not attend training at farmer training center. Hence, attending training at farmer training center was increase farmers chance to adopt small scale irrigation because it enables farmers to make right decision on how to apply irrigation on their farm land with minimum probability of risk and it empowers farmers to obtain on time irrigation technology information.

Access to credit affects farmer's probability of participation in irrigation use significantly and positively at $5 \%$ significance level. The positive relationship could be because those households who have access to credit have a better possibility of getting farm inputs and hence the probability of participation in small scale irrigation increases. Keeping other variables fixed, availability of credit service encourages the likelihood of household small scale irrigation adoption decision by $14.77 \%$. The finding is in line with Godfrey et al., (2014). Therefore, this study revealed that the probability of adopting irrigation technology for households with credit access is higher than households without credit access. Contrary to this, the variable ethnicity of household was negative and had statistically significant influence at $1 \%$ level on the adoption of small scale irrigation. The result indicates that indigenous households are 20.76 percent of marginal effect less likely to participate in small scale irrigation; other things remain constant, as compared to their counterparts of new settler. The probable reason is due to most indigenous households are highly engaged in non-farm activity like on dig out of gold and other traditional activity than agricultural production in the study area. This implies most probably new settler households are highly participated in irrigation practice than indigenous households and it is statistically significant.

As expected, the availability of family labor force has positive impact on likelihood of small scale irrigation adoption at level of significance 5\%. The marginal effect verify that the availability of one more active person in family increase the probability of irrigation technology adoption by $4.6 \%$, holding all other factors constant. This finding is consistent with the results of Beshir, Emana, Kassa, \& Haji (2012), which reason out that improved farm practices including irrigation are labor intensive and hence the household with relatively high labor force uses the technologies on their farm plots better than those with little labor force in family.

\section{Results of the second stage of Heckman two stage model (OLS model)}

The Heckman model in the second stage estimation identifies the factors that determine the intensity of small scale irrigation adopted using the OLS model. The coefficient of inverse Mill's ratio /Lambda is significant at 1\% level. The significance of Mill's ratio discloses the presence of selection bias and the effectiveness of applying Heckman 
two stage models due to its ability to handle the selection problem. The positive sign of lambda reflects that the error terms in the adoption decision model and selection equations are positively correlated.

Table 6 reveals that the regression results of variables that affect the level of small scale irrigation adoption among smallholder farmers. Out of 13 explanatory variables family size, credit use, ethnicity and lambda significantly influence the intensity of small scale irrigation adoption. Accordingly, the interpretations of each significant variable were explained here under.

Table 6: Results of the second stage selection estimation (intensification of small scale irrigation adoption)

\begin{tabular}{lllll}
\hline Variables & Coefficient & Std. Err. & Z & \multicolumn{1}{l}{$\mathbf{P}>|\mathbf{z}|$} \\
\hline Aghh & .0011595 & .0026165 & 0.44 & 0.658 \\
Sexhh & .0124763 & .0416521 & 0.30 & 0.765 \\
Fshh & $.0205717^{*}$ & .0112308 & 1.83 & 0.067 \\
Livow & -.002909 & .0051349 & -0.57 & 0.571 \\
Parlfor & .0056982 & .0112653 & 0.51 & 0.613 \\
Distirr & .0546838 & .0392632 & 1.39 & 0.164 \\
Distmkt & $\mathbf{. 0 0 0 4 9 2 4}$ & $\mathbf{. 0 0 4 8 0 6 1}$ & $\mathbf{0 . 1 0}$ & $\mathbf{0 . 9 1 8}$ \\
Eduhh & $\mathbf{. 0 4 6 5 0 8 6}$ & $\mathbf{. 0 3 8 6 3 7}$ & $\mathbf{1 . 2 0}$ & $\mathbf{0 . 2 2 9}$ \\
Ethi & $\mathbf{. . 0 8 1 0 3 0 7 * *}$ & $\mathbf{. 0 4 1 3 7 0 4}$ & $\mathbf{- 1 . 9 6}$ & $\mathbf{0 . 0 5 0}$ \\
Duresi & $\mathbf{. 0 0 3 5 1 0 1}$ & $\mathbf{. 0 0 3 2 6 6 2}$ & $\mathbf{- 1 . 0 7}$ & $\mathbf{0 . 2 8 3}$ \\
Offfarm & $\mathbf{. 0 4 8 8 2 6}$ & $\mathbf{. 0 3 4 3 7 2 1}$ & $\mathbf{1 . 4 2}$ & $\mathbf{0 . 1 5 5}$ \\
Usecrids & $\mathbf{. 0 9 4 6 5 5 4 * * *}$ & $\mathbf{. 0 3 5 7 1 9}$ & $\mathbf{2 . 6 5}$ & $\mathbf{0 . 0 0 8}$ \\
Atftc & $\mathbf{. 0 7 1 3 9 1 9}$ & $\mathbf{. 0 5 0 7 0 0 7}$ & $\mathbf{1 . 4 1}$ & $\mathbf{0 . 1 5 9}$ \\
Mills lambda & $\mathbf{. 1 9 5 9 6 3 6}$ & $\mathbf{. 0 7 1 8 0 7 6}$ & $\mathbf{2 . 7 3}$ & $\mathbf{0 . 0 0 6}$ \\
Con & $\mathbf{. 6 0 6 4 9 5 8}$ & $\mathbf{. 6 6 5 3 1 6}$ & $\mathbf{2 . 2 8}$ & $\mathbf{0 . 0 2 3}$ \\
\hline
\end{tabular}

Number of observation $=329 ;$ Censored observation $=146 ;$ Uncensored Observation $=183 ;$ Wald $_{\text {chi }}{ }^{2}(13)=$ 22.53; Prob $>c h i^{2}=0.0476$

$* * *, * *$ and $*$ imply statistically significant at 1,5 and $10 \%$ respectively.

Source: Computed from own survey data (2020)

Analogous to the first stage result, credit use and ethnicity determine both adoption decision and intensity of adoption significantly with expected sign. Moreover, family size has positive and significant effect on intensity of adoption at $10 \%$ level of significance. Access to credit service was found significantly and positively influencing the intensity of participation in small scale irrigated farming by the farmers, at $1 \%$ level of significance. From the result of second stage OLS regression, it indicates that the proportion of land covered by irrigation increases by about 0.09 hectare for credit user farmers as compare to the farmer who did not use credit. This suggests that households, who had access to credit service, are more likely to intensify small scale irrigation adoption than farmers who did not used credit by about 0.09 hectare, holding other factor constant. This finding is in line with the result reported by Abebe et al., (2011).

Family size of the farm household head also found positive and significant influence on intensity of small scale irrigation adoption at 10\% significance level. One additional person in family enhances the use of proportion of land irrigated by 0.02 hectare, holding all other variables constant. In the same genre, ethnicity of the farm household head is also shown expected sign and statistically significant at $5 \%$ level. This suggests that the proportions of land irrigated by indigenous farmers are less than the proportion of land irrigated by new settler households by about 0.08 hectare, keeping other variables constant.

Regarding the effect of the remaining variables, age of household head, participation in non-farm activity, education, duration of residence, livestock ownership, sex of the head, distance to irrigation, distance to market, active labor force and attending training at farmer training center were statistically insignificant to influence the intensity of small scale irrigation adoption.

\section{CONCLUSION AND POLICY IMPLICATION \\ Conclusion}

A remarkable improvement in agricultural productivity in majority of developing countries in late 1960s resulted from agricultural transformation agenda including of agricultural research, extension services and rural infrastructural development that basically underline the role technology adoption among smallholder's farmer in increasing production was vital. Technological change in agriculture comprises of introduction of high yielding variety of seeds, fertilizers, plant protection measures and irrigation. These changes in agricultural sector augment the productivity per unit of land and bring about rapid increase in production to tackle the severe problem of poverty. In Ethiopia, even though some progress has been recorded over time, the use of agricultural technologies especially irrigation is found at its low level signifying the role of empirical studies. To this end, this study was conducted with the aim of investigating the institutional, demographic and socioeconomic factors that influence the adoption decision and extents of small scale irrigation among smallholder farmers. Accordingly, the descriptive 
statistics and Heckman two stage econometric methods were employed to analyze data collected from sampled household. The significance of coefficient of inverse Mill's ratio $(\lambda)$ indicates the presence of selection bias and the effectiveness of applying Heckman two stage model.

The adoption decision of small scale irrigation use was driven by factors such as ethnicity, sex, education status of the head, size of cultivable land, development agent advice, access to credit, attending training at farmer training center, distance to irrigation, active labor force and total livestock unit. While the intensity of small scale irrigation application was influenced by family size, access to credit, ethnicity of farm household and lambda.

\section{Policy implication}

In light of these findings, development agent advice and education status of the head is being a crucial factor in enhancing the farmer small scale irrigation adoption. Therefore, it is suggested that policy makers should targeted the extension program to the less educated farmers for its effective delivery through special training, seminars, field demonstrations, and technical support to enhance the adoption rate of small scale irrigation. Moreover, the policies which expand the accessibility of credit service, dissemination of productive agricultural technology information, and creating opportunity of education for farm house hold has potential to increase the chance of small scale irrigation adoption decision and strengthen the level of adoption among smallholder farmers.

\section{Reference}

Abebaw, A. \& Mesfin, T. (2015). Determinants of small scale irrigation utilization by smallholder farmers in rift valley basin, Woliata zone, Ethiopia. Journal of Natural Sciences Research.

Abebe, E., B, K. \& Gebremedhin, Y. (2011). Determinants of land allocation to irrigation and its wealth effect: Evidence from northern Ethiopia. Journal of the Dry lands, 4(2): 310-319.

Abraham, B., Araya, H., Berhe, T., Gujja, B., Khadka, R., Sen, D., Koma, Y., Sharif, A. \& Styger, E. (2014). The system of crop intensification: Reports from the field on Improving agricultural production, food security, and resilience to climate change for multiple crops. Addis Ababa, Ethiopia.

Astatike, A.A. (2016). Assessing the impacts of small scale irrigation schemes on household income in Bahir Dar Zuria Woreda (Masters thesis), Haramaya University, Harer, Ethiopia.

Beshir, H., Emana, B. \& Kassa, B. (2012). Determinants of chemical fertilizer technology adoption in North eastern highlands of Ethiopia . Journal of Research in Economics and International Finance, 1(2), 39-49.

Beyan, A., Jema, H. \& Adem, K. (2014). Effect of small scale irrigation on the farm households' income of rural farmers: The case of Girawa district, East Hararghe, Oromia, Ethiopia. Asian Journal of Agriculture and Rural Development, 4(3): 257-266.

BoFED. (2017). Bureau of finance and economic development.

FAO. (2017). Food and Agricultural Organization food security Situation report Addis Ababa, Ethiopia.

Feder, G., Just, R.E \& Zilberman, D. (1985). Adoption of Agricultural Innovation in Developing Countries: A survey. Economic Development and Cultural Change, 33(2), 255-298.

Gashaw, T., Alan, B., Nicholas, M. \& Tanguy, B. (2014). The impact of the use of new technologies on farmers wheat yield in Ethiopia. International Food Policy Research Institute (IFPRI). Washington.

Gebregziabher, G., Namara, R. E.\& Holden, S. (2012). Techniqal efficiency of irrigated and rain- fed small holder agriculture in Tigray, Ethiopia; A Comparative Stochastic Frontier Production Function Analysis. Quarterly Journal of International Agriculture, 51, 51(53): 203-226.

Greene W. H. (2007). Econometric Analysis, sixth edition. New York, 07458. USA: Pearson Education, Inc., Upper Saddle River.

Gujarati, D. (1995). Basic Econometrics. Third edition. New York, USA: Mc Graw Hill Book Company, Inc.

Heckman J. (1979). Sample Selection Bias as a Specification Error. Econometrica, 47, 153161.http://dx.doi.org/10.2307/1912352.

Kidanemariam. G. \& Daniel. M . (2017). impact of micro-irrigation on households' welfare in the northern part of Ethiopia. Studies in Agricultural Economics, 119, 160-167.

Kinfe, A. (2012). Effects of small -scale irrigation on the income of rural farm households: The case of Laelay Maichew district, central Tigray, Ethiopia. The Journal of Agricultural Science, 7(1), 43-57.

Leta, L., Abayneh, A. \& W, T. (2018). Impact of Small Scale Irrigation on Household Farm Income and Asset Holding: Evidence from Shebedino District, Southern Ethiopia. Journal of Resources Development and Management, ISSN 2422-8397, Vol.43, 2018.

Mendola, M. (2007). Agriculture technology adoption and poverty reduction: A propensity score matching analysis for rural Bangladish . Food Policy, 32 : 372-393.

Ogunniyi, A., Omonona, B., Abioye, O. \& Olagunju, K. (2018). Impact of irrigation technology use on crop yield, crop income and household food security in Nigeria: A treatment effect approach. Journal of agriculture development, 3(2): 154-171.

Pokhrel, B., Krishna, P. \& Eduardo, S. (2016). Factors Affecting the Choice, Intensity, and Allocation of Irrigation 
Technologies by US Cotton Farmers. Annual Meeting, San Antonio, Texas (No. 230199).

Ray G.L. (2001). Extension communication and management. Second Edition. Naya Prokash, Calcutta.

Temesgen, H. (2018). Participation in and impact of Small-Scale Irrigation Practice on household income: The case of Abay Chomen District of Oromia national regional state, Ethiopia. Journal of Development and Agricultural Economics, Vol. 10(12), pp. 384-393.

Tsegazeab, G. (2016). Adoption and Impact of Micro Irrigation on Households Income: The case of Bambasi Woreda. Proceedings of the 8th Multi-Disciplinary Seminar, (pp. 85-96).

Wang, J., Klein, K.K., Lijuan Zhang \& Wencui, Z. (2015). Adoption of improved irrigation scheduling methods in Alberta: An empirical analysis. Canadian Water Resources Journal, 40(1):47-61.

World Bank. (2014). Ethiopia poverty Assessment. Document of the WB for official use only.

Yeman, T. (1967). Statistics, an Introduction Analysis, 2nd Edition., New York: Harper and Row. 